\title{
Status epilepticus 2020
}

\author{
Janszky József dr. ${ }^{1,2}$ - Bóné Beáta dr. ${ }^{1}$ - Horváth Réka dr. ${ }^{1}$ \\ Sütő Zsófia dr. ${ }^{1}$. Szapáry László dr. ${ }^{1}$ - Juhos Vera dr. ${ }^{3}$ \\ Komoly Sámuel dr. ${ }^{1,2}$ - Kovács Norbert dr. ${ }^{1,2}$
}

${ }^{1}$ Pécsi Tudományegyetem, Általános Orvostudományi Kar, Neurológiai Klinika, Pécs ${ }^{2}$ MTA-PTE Klinikai Idegtudományi Képalkotó Kutatócsoport, Pécs ${ }^{3}$ EPIHOPE Epilepszia Központ, Budapest

\begin{abstract}
A status epilepticus a második leggyakoribb, sürgősségi kezelést igénylő neurológiai állapot. Halálozása 15-25\%. A „time is brain” elve a status epilepticus kezelésére is igaz: minél korábban kezdjük a megfelelő kezelést, annál nagyobb valószínúséggel tudjuk megállítani a progressziót. Magas szintú evidenciákon alapuló kezelési protokollal a status epilepticus progressziója az esetek 75-90\%-ában megelőzhető, az indukált kóma és a halálos kimenetel elkerülhető. A status epilepticus kezelése akkor a legsikeresebb, ha már a korai szakban megkezdjük a parenteralis benzodiazepinterápiát: im. midazolám $(0,2 \mathrm{mg} / \mathrm{tskg}$, max. $10 \mathrm{mg})$. Szabad véna esetén lehet vénásan is adni a benzodiazepint (10 mg diazepám iv). Ha az első benzodiazepinbolusra nem reagál a status epilepticus, állandósult (benzodiazepinrefrakter) status epilepticusról beszélünk. Ilyenkor a benzodiazepin ismétlésével párhuzamosan nem benzodiazepin típusú, gyorsan ható vénás antiepileptikumot is adni kell: iv. valproát $(40 \mathrm{mg} / \mathrm{kg}$, max. $3000 \mathrm{mg}, 10$ perc alatt $)$ vagy levetiracetám $(60 \mathrm{mg} / \mathrm{kg}$, max. $4500 \mathrm{mg}, 10$ perc alatt) javasolt. Az l órán túl is tartó, sem benzodiazepinre, sem antiepileptikumra nem reagáló, refrakter status epilepticust neurointenzív osztályon, teljes narcosissal (indukált kómával) kell kezelni. Az indukált kómát gyors hatású anesztetikummal lehet elérni, elsősorban propofol-midazolám kombinációval.

Orv Hetil. 2020; 161(42): 1779-1786.
\end{abstract}

Kulcsszavak: status epilepticus, benzodiazepin, valproát, levetiracetám, COVID-19

\section{Status epilepticus 2020}

Status epilepticus is the second most common neurological emergency with $15-25 \%$ mortality rate. The principle of "time is brain" is also true for the treatment of status epilepticus: the earlier we start an adequate treatment, the more likely we are to stop progression. With treatment protocols based on high-level evidence, the progression of status epilepticus can be prevented in $75-90 \%$ of cases: we can avoid the induced coma or death. At the beginning of status epilepticus, parenteral benzodiazepine should be given immediately: intramuscular midazolam $(0.2 \mathrm{mg} / \mathrm{kg}, \max .10$ $\mathrm{mg}$ ). In the case of easy veinous access, benzodiazepines can also be given intravenously. If the first benzodiazepine bolus does not stop the status epilepticus, we speak about established (benzodiazepine refractory) status epilepticus. In this case, a fast-acting non-benzodiazepine antiepileptic drug should be given: intravenous valproate $(40 \mathrm{mg} / \mathrm{kg}$, max. $3000 \mathrm{mg}$, within 10 minutes) or levetiracetam $(60 \mathrm{mg} / \mathrm{kg}$, max. $4500 \mathrm{mg}$, within 10 minutes $)$. Refractory status epilepticus that persists for more than 1 hour and does not respond to either benzodiazepines or antiepileptics should be treated with general anesthesia (full narcosis). Induced coma can be achieved with fast-acting anesthetics, a combination of propofol with midazolam is the most frequently used one.

Keywords: status epilepticus, benzodiazepine, valproate, levetiracetam, COVID-19

Janszky J, Bóné B, Horváth R, Sütő Zs, Szapáry L, Juhos V, Komoly S, Kovács N. [Status epilepticus 2020]. Orv Hetil. 2020; 161(42): 1779-1786.

(Beérkezett: 2020. május 17.; elfogadva: 2020. május 25.)

\section{Rövidítések}

CK = kreatinkináz; CYP2B6, CYP2C9, CYP3A4 = enzimek; COVID-19 = (coronavirus disease 2019) koronavírus-betegség 2019; EEG = elektroencefalográfia; EKG = elektrokardiog- ráfia; $\operatorname{ESETT}=($ established status epilepticus treatment trial $)=$ az állandósult status epilepticus kezelését célzó klinikai vizsgálat; FIRES = (febrile infection-related epilepsy syndrome) láz indukálta epilepsziaszindróma; FLAIR/T2 = T2-weighted- 
fluid-attenuated inversion recovery; GABA = (gamma-aminobutyric acid) gamma-aminovajsav; IgG = immunglobulin-G; ILAE $=($ International League Against Epilepsy) Nemzetközi Epilepsziaellenes Liga; $\mathrm{MgSO}_{4}=$ magnézium-szulfát; $\mathrm{MRI}=$ (magnetic resonance imaging) mágnesesrezonancia-képalkotás; NCSE = non-convulsiv status epilepticus; $\mathrm{NMDA}=\mathrm{N}$-metil-D-aszpartát; NORSE = (new-onset refractory status epilepticus) de novo rezidens status epilepticus; OGP = oligoclonalis gammopathia; PNER = pszichogén nem epilepsziás roham

A status epilepticus az akut stroke után a második leggyakoribb, sürgősségi kezelést igénylő neurológiai állapot; évente átlagosan 20-40/100 000 lakost érint, hazánkban tehát évi 2-3 ezer esettel kell számolnunk $[1,2]$. Az Orvosi Hetilapban utoljára 2002-ben Tóth és Futó tollából jelent meg összefoglaló a status epilepticus kezeléséről [3]. A jelen összefoglaló aktualitását mégis az adja, hogy: (i) Változott a status epilepticus definíciója és súlyossági klasszifikációja. (ii) Megváltoztak a kezelési protokollok: immár több központú kettős vak-, randomizált tanulmányok alapján tudunk kezeléseket választani. (iii) Kiderült, hogy a de novo, ismeretlen eredetú status epilepticusok jó része mögött autoimmun encephalitis áll, direkt terápiás következményekkel. (iv) Szemléletváltás történt a non-convulsiv status epilepticus diagnózisában és kezelésében. (v) Felső légúti járványok (például COVID-19) alatt a status epilepticus minél hatékonyabb kezelése kiemelten fontos: mindent meg kell tennünk, hogy időben adekvát kezelést kapjon a beteg, így elkerülhetjük a rezisztens status epilepticus kialakulását. Ez utóbbi akár napokon/heteken át tartó általános anesztéziát (indukált kómát), lélegeztetést és intenzív ellátást igényel, lefoglalva a szúkös intenzív terápiás és lélegeztetési kapacitást [4].

A Nemzetközi Epilepsziaellenes Liga (ILAE) 2015ben megjelent definíciója alapján convulsiv status epilepticusról beszélünk, ha állandósul az epilepsziás aktivitás: a rohamok ismétlődnek, és a beteg a rohamok közötti időszakban nem tisztul fel, vagy a rohamok több mint 5 percig tartanak [5].

Status epilepticus bármely epilepsziás rohamformából kifejlődhet. Sürgősségi kórkép a convulsiv status epilepticus, amikor grand mal, illetve kiterjedt clonisatióval járó rohamok jelentkeznek halmozottan. Ez megfelelő kezelés nélkül életveszélyes állapot, halálozása az akut szakban 15-25\% [2, 6]. Így azonnali beavatkozást, összehangolt interdiszciplináris ellátást tesz szükségessé. A mortalitás (és különösen a hosszú távú mortalitás) elsősorban az etiológiától függ $[2,6]$, de az életkor és a status epilepticus súlyossága (hossza) is döntő tényező. Ebből a status epilepticus fennállási ideje az egyetlen befolyásolható tényező, melyet döntően az határoz meg, hogy a beteg az első órában megfelelő terápiát kap-e [7].

Fontos kiemelni, hogy a status epilepticus mögött az esetek kb. felében nem epilepszia, hanem akut neurológiai betegségek állnak: gyulladás (neuroinfekció, autoimmun encephalitis), stroke, subarachnoidealis vérzés, si- nusthrombosis, koponyatrauma, intoxikáció, kábítószer (például szintetikus kannabinoid) vagy annak megvonása $[2,7,8]$.

Míg ismert epilepsziás beteg egyszeri rohama esetén (amennyiben a beteg nem sérül meg) semmilyen kórházi kezelés vagy akut gyógyszeres kezelés nem szükséges, addig a status epilepticus már a helyszínen kezelendő állapot, melyet követően a beteget sürgősséggel neurointenzív ellátást adó osztályra kell szállítani [7].

Az epilepsziás rohamok többsége 1,5-2 percen belül spontán oldódik. Ha egy roham nem szúnik meg spontán 5 perc alatt, vagy ismétlődik, akkor az első ellátásban minden egyes perc késlekedés növeli annak lehetőségét, hogy a status 1 órán túl is tartani fog: a status epilepticus kezelése „harc az idővel”. Amennyiben késlekedünk a benzodiazepin adásával, vagy a benzodiazepin adása ellenére is folytatódik a rohamaktivitás, olyan agyi receptoriális változások alakulnak ki, hogy a status epilepticus egyre kevésbé fog reagálni benzodiazepinekre. Az idő előrehaladtával így egyre valószínütlenebb lesz, hogy a status epilepticust teljes anesztézia nélkül oldani lehet. Ez azt is jelenti, hogy az ellátás legfontosabb lépése a megfelelő benzodiazepinkezelés: megfelelö benzodiazepint kell választani, melyet megfelelö időben, megfelelö dózisban, megfelelö úton kell adni [7].

\section{A status epilepticus stádiumai (1. táblázat)}

Az idő függvényében beszélünk korai status epilepticusról (30 percen belül) és állandósult status epilepticusról (30 percen túl). Ha a status epilepticus benzodiazepinre nem reagál, akkor automatikusan állandósult status epilepticusról beszélünk. Refrakter status epilepticusról beszélünk akkor, ha benzodiazepin adását követően egy vagy két - adekvát módon és mennyiségben alkalmazott - nem benzodiazepin antiepileptikum ellenére 1 órán túl fennmarad a status epilepticus. Szuperrefrakter status epilepticusról akkor beszélünk, ha 24 órán túli disconnectio ('burst-suppression ' EEG melletti általános anesztézia) után is folyamatosan fennáll vagy újraindul a status epilepticus $[5,7]$.

\section{A status epilepticus differenciáldiagnózisa}

A convulsiv epilepsziás rohamok legfontosabb differenciáldiagnózisa a convulsiv syncope és a pszichogén nem epilepsziás roham. Prehospitális körülmények között a convulsiv syncope, míg kórházon belül a pszichogén nem epilepsziás rohamok jelentik a legnagyobb kibivást, mivel ez utóbbiak gyakran halmozottan jelentkeznek, pseudostatus képében. A pszichogén nem epilepsziás roham (PNER, „pseudoroham”) a konverziós zavar egyik gyakori manifesztációja; típusosan fiatal felnőtt korban kezdődik, és 75\%-ban nőket érint. A differenciáldiagnózis fontos szempontja, hogy a pszichogén rohamok többsége percekig, akár fél óráig eltart, lefolyásuk hullámzó és változó, szemben az epilepsziás roham sztereotip zajlásával, 
1. táblázat |A status epilepticus stádiumai és terápiás elvei

1. Korai status epilepticus

5-max. 30 perc

Terápia: BENZODIAZEPIN:

- ha nincs véna: $\mathrm{im} .10 \mathrm{mg}(0,2 \mathrm{mg} / \mathrm{kg})$ midazolám;

- ha van véna: iv. $10 \mathrm{mg}(0,2 \mathrm{mg} / \mathrm{kg})$ diazepám vagy im. $10 \mathrm{mg}(0,2 \mathrm{mg} / \mathrm{kg})$ midazolám

2. Állandósult status epilepticus

30-max. 60 perc, vagy ha az első BENZODIAZEPIN nem hatott

Terápia: BENZODIAZEPIN ismétlése + nem benzodiazepin ANTIEPILEPTIKUM:

- valproát: $40 \mathrm{mg} / \mathrm{kg}$ (max. $3000 \mathrm{mg}$ ) 10 perc alatt, majd $1 \mathrm{mg} / \mathrm{kg} /$ óra

vagy

- levetiracetám: $60 \mathrm{mg} / \mathrm{kg}$ (max. $4500 \mathrm{mg}$ ) 10 perc alatt, majd $1 \mathrm{mg} / \mathrm{kg} /$ óra

3. Refrakter status epilepticus

$>60$ perc vagy sem BENZODIAZEPIN, sem ANTIEPILEPTIKUM nem hatott

Terápia: indukált kóma + nem benzodiazepin ANTIEPILEPTIKUM

4. Szuperrefrakter status epilepticus

24 órás indukált kóma ellenére is tart

Terápia: indukált kóma másik anesztetikum, antiepileptikum-váltás, immunológiai kezelés

lépcsőzetes lefolyásával. Az epilepsziás rohamok jellemzően másodpercektől max. 2 percig tartanak. A PNERre jellemző: az egész test „rázása”, fejrázás, zárt szem mellett zajló roham, agonista-antagonista izmok alternáló „clonisatiója”, opisthotonus, kétoldali motoros jelenségek megtartott tudat mellett, mely utóbbi epilepsziában nagyon ritka. Pszichogén rohamokban ritka a postictalis confusio, izomláz, afázia, laterális nyelvharapás, enuresis. A PNER-ben ritka a súlyos sérülés, apró sérülések azonban előfordulhatnak. A PNER, „átványos”, azaz a rohamra odafigyelnek azok, akik a közelben vannak, így sokszor közterületen zajlik [7].

Igen gyakori, hogy a „rezisztens” status epilepticus diagnózis valójában pseudostatust (halmozott PNEReket) takar. A pszichogén és az epilepsziás rohamok közötti differenciálás sokszor problematikus: a pseudorohamok sokszor olyannyira megtévesztők tudnak lenni, hogy tapasztalt neurológus sem tudja elkülöníteni őket az epilepsziás rohamoktól. Amennyiben nem egyértelmú, hogy status epilepticusszal vagy halmozott PNERrel van dolgunk, érdemes a rohamokat videóra venni (például okostelefonnal), és akár telemedicina keretében neurológiai/epileptológiai konzíliumot kérni [7].

\section{A status epilepticus kezelése}

A status epilepticus ellátásában alapvető a hármas szabály betartása: a vitális paraméterek folyamatos monitorozása és stabilizálása mellett az etiológiai tényező (alapbetegség) korai tisztázása és gyógyitása, valamint a status epilepticus adekvát kezelése a cél $[7,9]$.

\section{A korai status epilepticus ellátása (prehospitális kezelés, 0-30 perc)}

A status epilepticus kezelése akkor a legsikeresebb, ha már a korai szakban megkezdjük a benzodiazepinterápiát. A gyors beavatkozással a korai szakaszban az esetek 5075\%-ában meg tudjuk állítani a status epilepticust. Kísérletes és humán adatok is azt igazolják, hogy minél gyorsabban kezdjük meg a benzodiazepin adását, annál valószínúbb a status epilepticus leállása. A rohamaktivitás során ugyanis idővel változik az agy receptoriális rendszere, ez magyarázza, hogy a későn beadott benzodiazepin kevésbé hatásos. Tehát a „time is brain” a status epilepticusra is igaz: a GABAerg rendszer aktiválását minél előbb kell elkezdeni.

Status epilepticusban a szabad, átjárható légutak biztosítása és a vitális paraméterek ellenőrzése után a gyógyszeres kezelést kötelezó elkezdeni, és mindig benzodiazepint kell adni; egyetlen kivétel a terhességi eclampsia, amikor $\mathrm{MgSO}_{4}$ az első választandó kezelés. A kórházi körülmények között választandó benzodiazepin lehet midazolám (intramuscularis, intravénás, buccalis, intranasalis), diazepám (intravénás és rectalis), klonazepám (intravénás), lorazepám (intravénás). Hazánkban a lorazepám - mely a vénás úton történő beadás esetén a legjobb választás lenne - sajnos nem érhető el parenteralisan.

Benzodiazepin adása előtt a vitális paramétereket ellenőrizni, a szabad légutat biztosítani kell (szükség esetén nasopharyngealis tubus használata, végső esetben intubáció). Mivel a korai status epilepticus egyetlen komoly szövődménye a légzésdepresszió, $\mathrm{O}_{2}$ adása, $\mathrm{O}_{2}$-szaturáció-mérés és lélegeztetésre való felkészülés javasolt. Az összes többi eszközös vizsgálat (vérnyomás, EKG, vércukormérés) csak a benzodiazepin beadása után javasolt, hiszen a status 5. percétól fokozatosan csökken a benzodiazepinre történő válaszkészség. Vércukorméréssel azért sem érdemes húzni az időt, mert a rohamok max. $2 \%$-át okozza hypoglykaemia: sokkal fontosabb, hogy minél gyorsabban beadjuk a benzodiazepint, és csak utána mérjünk cukrot [1].

Korábban hagyományosan prehospitálisan is az iv. benzodiazepin adását részesítették előnyben, a 2012ben megjelent randomizált vizsgálat [10] azonban azt találta, hogy prehospitálisan az im. midazolám hatékonyabb, mint a vénás lorazepám. A különbség oka valószínúleg abban rejlik, hogy im. adáskor nem kell vénát „keresni" a roham alatt, a beadás ezen útja sokkal gyorsabb. Im. midazolám az esetek 73,4\%-ában, iv. lorazepám a 63,4\%-ában állította le a rohamokat prehospitális körülmények között. Ezért a legtöbb nemzeti prehospitális protokollban a status epilepticus kezelésének elsö lépése az im. midazolám (0,2 mg/tskg, max. $10 \mathrm{mg}$ ). Szabad véna ese- 
tén lehet vénásan is adni a benzodiazepint: $10 \mathrm{mg}$ diazepám iv. [11].

A midazolámot korai status epilepticusban szigorúan im. kell alkalmazni. Az iv. adott midazolámnak - bár összehasonlító vizsgálat nem történt - feltehetőleg roszszabb a hatása a diazepáménál a túl gyors farmakokinetika miatt. Ugyanígy, a midazolám kivételével egyéb benzodiazepin im. adása nem ajánlott status epilepticusban. Iv. diazepám vs. klonazepám összehasonlító vizsgálat nem történt.

Egy randomizált, kontrollált vizsgálat [12] egy másik tévhitet döntött meg: iv. benzodiazepinkezelés mellett ritkábban lép fel légzésdepresszió, mint iv. placebo mellett. Status epilepticusban a légzésdepresszió oka ugyanis elsősorban a postictalis szak jellegzetessége, semmint gyógyszerhatás, tehát ha megfelelően és időben kezeljük a status epilepticust, a légzésdepresszió is ritkább. Ettől függetlenül az iv. benzodiazepinnek van légzésdeprimáló hatása, ezért relatíve lassú, de egyszerre - 1-2 perc alatt történő - iv. adás javasolt. Szintén tévhit, hogy benzodiazepint mindig a rohamok alatt kell beadni: az elsődleges cél a további klinikai rohamok megakadályozása. Roham alatt egyébként is csak im. midazolám adására van lehetőség, hiszen a clonusos szak során gyakorlatilag lehetetlen vénát biztosítani. A felnőttkori grand mal status során ugyanis nem folyamatos a klinikai roham, hanem legalább 5 perc szünet van két roham között: a benzodiazepinnel nem az aktuális rohamot, hanem a klinikai rohamok ismétlődését állítjuk le [12].

Amennyiben injekció adására nincs mód (például az ellátást végző személyzetnek nincs kompetenciája invazív beavatkozásra, vagy laikus kezdi el a satus epilepticus kezelését, mint például lázgörcsre hajlamos kisgyermeknél a szülő), akkor intranasalisan vagy buccalisan adott midazolám (0,2 mg/tskg, max. $10 \mathrm{mg}$ ) javasolt. Ennek alternatívája a rectalis diazepámoldat $(0,2-0,5 \mathrm{mg} / \mathrm{tskg}$, max. 10-20 mg), de ez utóbbi hatása gyengébb (hiszen a beadás körülményesebb), és szociálisan kevésbé fogadható el. A nem injekciós formában adott benzodiazepinek esetén a légzésdepresszió veszélye alacsony.

A korai status epilepticus komplikációja lehet a légzésdepresszió (10-15\%), a hypotensio $(25-30 \%)$, a cardialis arrhythmia $(2-7 \%)[1]$.

\section{Az állandósult status epilepticus kezelése (30-60 perc)}

Ha az első benzodiazepinbolusra nem reagál a status epilepticus, akkor megismételhetjük a benzodiazepin adását, de ekkor - feltehetőleg az agyi receptoriális rendszerek megváltozása miatt - már gyengül a hatása, ezért nem benzodiazepin típusú, gyorsan ható vénás antiepileptikumot is adni kell. Ez Magyarországon hagyományosan a fenitoin volt. Az utóbbi években számos új, intravénásan adható antiepileptikum is megjelent a palettán: valproát, levetiracetám vagy a lakozamid. Több, alacsony esetszámú vizsgálat alapján készült metaanalízis alapján az iv. valproát és iv. levetiracetám valamelyest hatékonyabb, mint az iv. fenitoin [13]. Az Egyesült Államokban több vizsgálat igazolta, hogy a foszfenitoinnak kevesebb a mellékhatása, mint a fenitoinnak, ezért ahol elérhető, ott a foszfenitoint preferálják a fenitoinnal szemben [11, 14]. Így érthető, hogy az egyetlen megfelelően tervezett, randomizált, kettős vakvizsgálat, mely az állandósult (benzoidazepinrefakter) status epilepticus első választandó kezelését hivatott eldönteni, a valproát vs. levetiracetám vs. foszfenitoin összehasonlításra épült.

Az ESETT-vizsgálat (Efficacy of levetiracetam, fosphenytoin, and valproate for established status epilepticus) nyújtja a legmagasabb evidenciaszintet a benzodiazepinrefrakter status epilepticus kezelésére [15]. A kettős vak-, randomizált kontrollált vizsgálatba 384 beteget vontak be: 145 beteg kapott vénás levetiracetámot, 118 foszfenitoint, 121 valproátot. A hatékonyság szempontjából nem volt különbség a három gyógyszer között, mindbárom csoportban 45-47\%-ban állt le a status epilepticus. A halálozás tekintetében nem szignifikáns különbség mutatkozott: foszfenitoin mellett $3(2,4 \%)$, levetiracetám mellett 7 (4,7\%), míg valproát mellett $2(1,6 \%)$ beteg hunyt el [15].

Figyelembe véve a korábbi metaanalízis-tanulmányokat [13] és különösen az ESETT-vizsgálatot [15], hazánkban a benzodiazepinrezisztens status epilepticus kezelésére elsősorban iv. valproát (40 mg/kg, max. $3000 \mathrm{mg}$, 10 perc alatt) vagy levetiracetám $(60 \mathrm{mg} / \mathrm{kg}$, max. 4500 mg, 10 perc alatt) javasolt. Az említett dozírozás az ESETT-ben alkalmazott adagolást tükrözi. Fontos megemlíteni, hogy ezek a dózisok jóval magasabbak, mint a fenntartó dózis, melyre a „telítő” dózist követően átállítjuk a betegeket; ez a telítést követő napra mind a valproát, mind a levetiracetám esetében $1-3 \mathrm{mg} / \mathrm{kg} /$ óra [7, 16]. Sajnos gyakori hiba az aluldozírozás, ami emeli a későbbi refrakteritás kialakulásának veszélyét (2. táblázat).

Mivel a levetiracetám és a valproát hatásossága között az ESETT nem tudott kimutatni lényeges különbséget, egyértelműen nem tudjuk megmondani, hogy mikor melyiket válasszuk. A valproát szélesebb spektrumú antiepileptikum, mint a levetiracetám, míg gyógyszer-interakciók és mellékhatás szempontjából a levetiracetám a kedvezőbb [16].

\section{A refrakter status epilepticus kezelése (60 percen túl is zajló, benzodiazepinre és vénás, nem benzodiazepin tipusú antiepileptikumra is rezisztens)}

A refrakter status epilepticust neurointenzív osztályon, teljes narcosissal (indukált kómával) kell kezelni. Ezt rövid hatású barbituráttal (pentobarbitál vagy tiopentál), midazolámmal, propofollal vagy ketaminnal érhetjük el. A teljes narcosist megfelelő mélységig kell folytatni úgy, hogy az EEG-n ún. 'burst-suppression' mintázat jelen- 


\section{2. táblázat |A status epilepticus kezelésének típushibái}

\begin{abstract}
- A benzodiazepin aluldozírozása.
- Diazepám és/vagy klonazepám intramuscularis adása.

- Nem benzodiazepin antiepileptikum adása benzodiazepin helyett: fenitoin, levetiracetám és valproát csak 15-60 perc alatt fejti ki hatását, ezért benzodiazepin adása nélkül, a status epilepticus kezelés korai szakaszában önállóan adni tilos!

- „Agyödéma-csökkentés”: a status epilepticus NEM jár agyödémával, agyödéma-csökkentő szerek adása felesleges, kivéve, ha az alapbetegség miatt szükséges.

- A rectalis karbamazepinnek nincs szerepe a status epilepticus akut kezelésében.

- Antiepileptikumok aluldozírozása: status epilepticus kezelése esetén több antiepileptikum kisebb adagjai helyett a választott szerek egyénre szabott maximális adagját használjuk.

- Refrakter status epilepticus esetében anesztéziánál az EEG-kontroll elmaradása.

- Fenyegető propofolinfúziós szindróma, labormarker-monitorozás elmaradása.

- Gyógyszer-interakciók figyelmen kívül hagyása: például valproátot karbapenem típusú antibiotikummal nem szabad kombinálni, míg fenitoin esetén az összes CYP450 enzimrendszeren metabolizálódó (enziminduktor) gyógyszer problémát okozhat.

- A status epilepticus leállása után az antiepileptikum-dózis visszakorrigálásának elmulasztása az antiepileptikum-intoxikáció veszélyét hordozza magában, mivel status epilepticusban a krónikus dózisoknál jóval magasabb adagot használunk: ezt a status epilepticus elmúltával le kell csökkenteni (különösen valproátnál fontos odafigyelni, hiszen itt az 'akut' dózis >3000-4000 mg/die, míg a krónikus $1000 \mathrm{mg} /$ die körül van, de a végső adagot a gyógyszervérszint alapján állítjuk be).

- Túlságosan „agresszív” kezelés Kozsevnyikov-epilepsziában vagy non-convulsiv status epilepticusban
\end{abstract}

CYP450 = citokróm P450 enzim; EEG = elektroencefalográfia

jen meg, és ezt fenn kell tartani 24 órán keresztül. Ilyenkor a corticalis aktivitás átmeneti felfüggesztésével „kiütjük" a status epilepticust [7].

Az indukált kómát minimum 24 óráig fenn kell tartani, és maximum 48 óra elteltével kell fokozatosan (további 24 óra alatt, kontrolláltan) megszüntetni, hogy a status epilepticus újraindulása esetén időben vissza lehessen térni az előző, hatékony kezeléshez, egy újabb 24 órás ciklust kezdve. Az indukált kóma alatt iv. vagy nasogastricus szondán keresztül antiepileptikum felépítését is el kell kezdeni, illetve folytatni lehet az állandósult status epilepticus fázisában adott antiepileptikumot, hiszen a kóma feloldása után, ha az alapbetegség nem oldódott meg, továbbra is szükséges az epilepsziás rohamok, illetve a status epilepticus prevenciója.

A rövid hatású narkotikum választását illetően nincsenek evidenciáink. Midazolám-monoterápiával rendszerint nem lehet tartósan 'burst-suppression' mintát elérni, így inkább kombinációban használatos. Ha mégis önmagában adjuk, 0,2 mg/kg telítés után a javasolt céldózis $0,1 \mathrm{mg} / \mathrm{kg} /$ óra, sikertelenség esetén fokozatosan akár 2 $\mathrm{mg} / \mathrm{kg} /$ óra.
Kis esetszámú tanulmányok és metaanalízisek alapján számos szakmai ajánlás inkább a propofolt javasolja elsöként választandónak a barbiturátokkal szemben [7, 17]. Ez praktikus is, hiszen az intubáció során a beteg úgyis kap propofolt. A dózisokat a leginkább a hatékonyság ('burst-suppression' stádium) és a mellékhatások (például propofolinfúziós szindróma veszélye) határozzák meg, de általában a propofolt a szokásos anesztéziai beavatkozásokhoz képest magasabb adagokban kell adni a mély kóma elérése céljából.

A legtöbb ajánlás $1-10 \mathrm{mg} / \mathrm{kg}$ /óra propofol dózissávot javasol. Egyes ajánlások - különösen szuperrefrakter status epilepticusban - akár $24 \mathrm{mg} / \mathrm{kg}$ /óra propofoldózist is javasolnak [18]. Fokozottan oda kell figyelni a propofolinfúziós szindrómára (3. táblázat): ez a tartósan és nagy dózisban alkalmazott propofol mellett gyakrabban lép fel. Minden betegnél, aki > 24 órán keresztül kap propofolt, vagy $>3,5 \mathrm{mg} / \mathrm{kg} /$ óra adagban kapja, legalább 12 óránként laktát-, CK-, triglicerid-, mioglobin-, $\mathrm{PH}-$ meghatározás javasolt folyamatos EKG-kontroll mellett; fokozottan kell odafigyelni a 'coved' típusú (a Brugadaszindrómához hasonló) ST-elevációra [19]. Mivel a propofolinfúziós szindróma dózis- és időfüggő, javasolt a propofollal való spórolás": a propofolt és a midazolámot kombináljuk, különösen 24 órán túli kezelés esetén (egyes centrumok ketaminnal vagy barbituráttal is javasolják kombinálni a propofolt) [20].

Külön entitás a teljesen egészséges emberekben fellépő, ismeretlen eredetü rezidens status epilepticus (NORSE, new-onset refractory status epilepticus). Oka igen gyakran NMDA-receptor-ellenes encephalitis [21]. Amikor nem tudunk ismert antitestet kimutatni (azaz nem áll fenn NMDA-encephalitis), kriptogén NORSEról beszélünk. A kriptogén NORSE - szemben az NMDA-encephalitisszel - nem jár sem pszichiátriai tünetekkel, sem dyskinesisekkel; jellemzően ismeretlen eredetű lázat követően lép fel, gyakran szimmetrikus MRI-eltérésekkel (FLAIR/T2 hiperintenzitás), és a

\section{3. táblázat |A propofolinfúziós szindróma}

Rizikócsoport: katecholamin, szteroid együttes adása, magasabb (>4 mg/kg/óra) propofoldózis, tartós (>24 óra) alkalmazás

- Megelőzés: korai felismerés (elsősorban rendszeres CK-, laktát- és trigliceridszint-monitorozással)

- Tünetei:

- Rhabdomyolysis (CK!!!)

- Metabolikus acidosis ( $\mathrm{pH}$-ellenőrzés)

- Hyperkalaemia

- Hyperlipidaemia

- Veseelégtelenség

- Cardialis szövődmény, mely a cardiovascularis rendszer összeomlásához vezethet szívizomelhalás következtében: az első jel a Brugada-szindrómához hasonló ('coved' típusú) ST-eleváció

$\mathrm{CK}=$ kreatinkináz 
liquorvizsgálat sem mutat oligoclonalis IgG (OGP-) képzést. Egyesek elkülönítik a kriptogén NORSE-nak a lázat követően fellépő formáját, a láz indukálta epilepsziaszindrómát (FIRES, febrile infection-related epilepsy syndrome). A FIRES elsősorban gyermekeket érint, és amennyiben a beteg túléli a többnyire szuperrefrakter status epilepticust, gyógyszerrezisztens epilepszia marad fenn. Kriptogén NORSE és FIRES esetében is az autoimmun mechanizmus a legvalószínúbb, így - a status epilepticus kezelése mellett - immunológiai terápia is javasolt: szteroid, plazmaferézis, immunglobulin, ciklofoszfamid, rezisztens esetekben: anakinra, rituximab, kannabidiol, ketogén diéta jön szóba. A kriptogén NORSE és FIRES gyakran megy át szuperrefrakter fázisba, sokszor hetekig tartó indukált kómát és lélegeztetést igényel, 12-27\%-os halálozással jár, maradványtünete - FIRES esetében - a gyógyszerrezisztens epilepszia $[21,22]$.

\section{Szuperrefrakter status epilepticus}

Ebben a stádiumban nincsenek evidenciaszintű ajánlások. A diagnózis felülvizsgálata javasolt, hiszen ritkán pseudostatus (halmozott PNER-ek) is jelentkezhet „szuperrefrakter” status epilepticus képében.

Mindenképpen ismételt (>24 óra) anesztézia javasolt, propofollal, propofol-midazolám kombinációval, barbituráttal, de szóba jön ketamin és lidokain is. A szuperrefrakter status epilepticusban az NMDA-receptorok számának növekedését mutatták ki mind a cortexben, mind a hippocampusban. A ketamin az egyetlen tiszta NMDA-antagonista vegyület, melynek előnyei közé tartozik a többi általános anesztetikumhoz képest, hogy alacsony a cardiorespiratoricus mellékhatása, és csökkenti a koponyaû́ri nyomást is. Ketamin alkalmazásakor azonban feltétlenül figyelembe kell venni a bázis-antiepileptikum választásakor, hogy CYP3A4-en, 2B6-on és 2C9-en keresztül metabolizálódik. Ugyanígy javasolt a párhuzamosan adott, nem benzodiazepin antiepileptikum felülvizsgálata (dózisemelés vagy -csere), NORSE esetében a már részletezett immunológiai kezelés [7, 16, $18,23]$.

\section{A status epilepticus prognózisa}

A statusok túlnyomó többsége (>70\%) a korai szakban leáll benzodiazepin adására. Megfelelő kezelés mellett a status epilepticus mortalitása akkor magas, ha súlyos alapbetegség áll mögötte (de mint említettük, a status epilepticusok többsége mögött súlyos, akut neurológiai betegségek húzódnak meg: a halálozás az alapbetegség és a status epilepticus szupraadditív szövődményei miatt magas). A mortalitást 4 alapvető tényező határozza meg:

1) A status epilepticus súlyossága, hossza. Refrakter status epilepticus 23-43\%-ban alakulhat ki, míg a szuperrefrakter status epilepticus előfordulási gyakorisága ennek a 15\%-a. Általánosságban elmondható, hogy a status epi- lepticus mortalitása 10-30\% között mozog, azonban a refrakter status epilepticus mortalitása már 30-50\%, míg a szuperrefrakter status epilepticus mortalitása meghaladja az 50\%-ot $[7,9]$.

2) A status epilepticust kiváltó alapbetegség. A legfontosabb prognosztikai faktor. Ha az alapbetegség egyébként is életveszélyes állapot (például encephalitis), jóval magasabb a halálozás. A legkedvezőbb kimenetelü az ismert epilepsziás beteg status epilepticusa, ha gyógyszerszedési pontatlanság, non-compliance vagy egyéb okból történő gyógyszerszintcsökkenés következtében lép fel $[2,7,8]$.

3) A beteg általános állapota, életkora. Az időskor, a rossz cardiopulmonalis status, az ágyhozkötöttség (például post-stroke-epilepszia) jelentősen megnöveli a halálos kimenetel veszélyét $[2,7]$.

4) Adekvát, időben elkezdett kezelés a status epilepticus stádiumainak függvényében. Ez természetesen nem független az 1-es faktortól, hiszen sokszor az inadekvát kezelés viszi bele a beteget a status súlyosabb változataiba, vagy ellenkezóleg - bár ez extrém ritka -, a túl gyorsan alkalmazott indukált kóma (általános anesztézia) okozza az intenzív terápia és a lélegeztetés szövődményeit, és késlelteti az alapbetegség tisztását is. A status epilepticus kezelésének típushibáit a 2. táblázatban foglaltuk össze $[2,7]$.

\section{Epilepsia partialis continua}

A status epilepticus különleges fajtája a stroke-hoz, tumorhoz és krónikus encephalitishez társuló ún. epilepsia partialis continua (Kozsevnyikov-epilepszia), melyet egy körülírt kéregterület folyamatos epilepsziás aktivitása okoz, és rendszerint kézben megnyilvánuló rángásokból (myoclonusokból) és clonusos rohamból áll. Ez az állapot napokig, encephalitisben évekig is eltarthat. Mivel ez önmagában nem életveszélyes állapot, a convulsiv status epilepticus kezeléséhez képest kevésbé kell „aktívan” közbeavatkozni (per os benzodiazepin, iv. vagy per os valproát vagy levetiracetám javasolt: a vigilitasszint mélyítésével nagyobb kárt okozunk, mint maga a status epilepticus: az alapbetegség zajlásával párhuzamosan változik a Kozsevnyikov-status) [7].

\section{Non-convulsiv status epilepticus}

Vannak olyan esetek, amikor a status epilepticus motoros jelenségek nélkül zajlik, ugyanakkor az EEG-n epilepsziásroham-aktivitás látszik.

A non-convulsiv epilepsziás status a leggyakrabban pszichés tünetekkel jár: dezorientáltság, megváltozott viselkedés, mentális tünetek, tudatzavar formájában jelentkezik, mely tünetek igen széles skálán mozoghatnak. Enyhe esetekben csak a beteget jól ismerőknek tűnik fel, hogy viselkedése kissé megváltozott, talán mintha „furcsább", feledékenyebb lenne. Lehet azonban a beteg olyan zavart és nyugtalan is, hogy pszichiátriai osztályra kerül. 
A non-convulsiv status epilepticus (NCSE) sokszor olyan betegekben is kialakul, akiknek korábban nem volt epilepsziás rohamuk, de egy-egy generalizált roham után, ha a beteg hosszabb ideig ( 30 perc) nem tisztul fel, fel kell vetni a non-convulsiv status lehetőségét. A non-convulsiv status epilepticus mögött állhat epilepsziabetegség, de metabolikus zavarok, gyulladásos folyamatok (encephalitis, meningitis), stroke, gyógyszermegvonás vagy intoxikáció egyaránt [7].

\section{Kómás betegnél észlelhetô", statusszerü EEG-minta}

Az EEG elengedhetetlen az NCSE diagnózisához. Mindazonáltal a status epilepticusra jellemző, de azzal nem teljesen azonos mintázatot látunk kómával járó, súlyos generalizált agyi diszfunkció (például anoxiás encephalopathia) esetében.

Komoly dilemma, ha kómába került betegnél status epilepticusra jellemző mintázatot látunk. A kibívást ilyenkor az jelenti, hogy az alapbetegség önmagában is mutathat status epilepticushoz hasonló EEG-jeleket (például periodikus minták herpes encephalitisben vagy anoxiás encephalopathiában), tehát nehéz eldönteni, hogy a kómáért az alapbetegség önmagában vagy az alapbetegség kiváltotta NCSE a felelős [24]. A kérdésnek direkt terápiás konzekvenciája van, hiszen ha nem áll fenn status epilepticus, akkor annak „kezelése” tovább mélyíti a kómát, gépi lélegeztetésre adhat okot, és a status epilepticus elleni gyógyszerek potenciális mellékhatásai tovább súlyosbíthatják a beteg általános rossz állapotát.

A kóma-NCSE aluldiagnosztizált, ha nincs EEG-hozzáférés az intenzív osztályon, viszont valószínúleg „túldiagnosztizált”, ha van EEG-hozzáférés. Ezért a kómaNCSE és a kómát kísérő nem epilepsziás, de az EEG alapján statusmintára emlékeztetố állapot elkülönítésére a Beniczky és Trinka vezette munkacsoport külön elektroklinikai kritériumrendszert (ún. módositott Salzburgkritériumok) dolgozott ki, ennek specificitása és szenzitivitása $90-95 \%[7,25]$.

\section{A non-convulsiv status epilepticus terápiája}

Az NCSE terápiája eltér a convulsiv status epilepticus terápiájától, mivel nincs szükség, „agresszí”” kezelésre, különösen primer (nem kómás) NCSE-ben. Az NCSE önmagában nem jelent életveszélyt. Vénás benzodiazepinek és iv. antiepileptikumok ajánlottak (például 'absence' statusban iv. valproát), indukált kóma alkalmazására csak extrém ritkán van szükség. Az alapbetegség kezelése a legfontosabb [7].

Anyagi támogatás: A közleményt az EFOP-3.6.2-162017-00008. számú, „A neuroinflammáció vizsgálata a neurodegeneratív folyamatokban: a molekulától a betegágyig" címú grant támogatta.

Szerzői munkamegosztás: Valamennyi szerző tevékenyen részt vett a közlemény tervezésében, kivitelezésében, szerkesztésében, kritikájában és revíziójában. J. J., K. N.: Tervezés, irodalmi adatok gyüjtése, közleményírás. B. B., H. R., S. Zs.: Kurrens irodalmi adatok átnézése, a közleményvázlat kritikai áttekintése. Sz. L., J. V., K. S.: Tanácsadás az irodalom gyüjtésére és feldolgozására, következtetések levonására. A közlemény végleges változatát valamennyi szerző elolvasta és jóváhagyta.

Érdekeltségek: A szerzőknek nincsenek érdekeltségeik.

\section{Irodalom}

[1] Silverman EC, Sporer KA, Lemieux JM, et al. Prehospital care for the adult and pediatric seizure patient: current evidencebased recommendations. West J Emerg Med. 2017; 18: 419436.

[2] Horváth L, Fekete I, Molnár M, et al. The outcome of status epilepticus and long-term follow-up. Front Neurol. 2019; 10: 427.

[3] Tóth K, Futó J. Status epilepticus and its treatment. [Status epilepticus és kezelése.] Orv Hetil. 2002; 143: 1339-1346. [Hungarian]

[4] Kinney MO, Brigo F, Kaplan PW. Optimizing status epilepticus care during the COVID-19 pandemic. Epilepsy Behav. 2020; 109: 107124

[5] Trinka E, Cock H, Hesdorffer D, et al. A definition and classification of status epilepticus - Report of the ILAE Task Force on Classification of Status Epilepticus. Epilepsia 2015; 56: 15151523

[6] Neligan A, Noyce AJ, Gosavi TD, et al. Change in mortality of generalized convulsive status epilepticus in high-income countries over time: a systematic review and meta-analysis. JAMA Neurol. 2019; 76: 897-905.

[7] Juhos V, Gyimesi Cs, Janszky J. Status epilepticus. In: Janszky J, Fogarasi A. (eds.) Clinical epileptology. [Status epilepticus. In: Janszky J, Fogarasi A. (szerk.) Klinikai epileptológia.] Medicina Könyvkiadó, Budapest, 2017; pp. 309-317. [Hungarian]

[8] Trinka E, Höfler J, Zerbs A. Causes of status epilepticus. Epilepsia 2012; 53(Suppl 4): 127-138.

[9] Rosdy B. Status epilepticus in childhood. In: Janszky J, Fogarasi A. (eds.) Clinical epileptology. [Status epilepticus gyermekkorban. In: Janszky J, Fogarasi A. (szerk.) Klinikai epileptológia.] Medicina Könyvkiadó, Budapest, 2017; pp. 318-320. [Hungarian]

[10] Silbergleit R, Durkalski V, Lowenstein D, et al. Intramuscular versus intravenous therapy for prehospital status epilepticus. $\mathrm{N}$ Engl J Med. 2012; 366: 591-600.

[11] Glauser T, Shinnar S, Gloss D, et al. Evidence-based guideline Treatment of convulsive status epilepticus in children and adults: report of the Guideline Committee of the American Epilepsy Society. Epilepsy Curr. 2016; 16: 48-61.

[12] Alldredge BK, Gelb AM, Isaacs SM, et al. A comparison of lorazepam, diazepam, and placebo for the treatment of out-of-hospital status epilepticus. N Engl J Med. 2001; 345: 631-637. [Correction: N Engl J Med. 2001; 345: 1860.]

[13] Trinka E, Höfler J, Leitinger M, et al. Pharmacologic treatment of status epilepticus. Expert Opin Pharmacother. 2016; 17: 513534.

[14] Aaronson PM, Belgado BS, Spillane JP, et al. Evaluation of intramuscular fosphenytoin vs intravenous phenytoin loading in the ED. Am J Emerg Med. 2011; 29: 983-988. 
[15] Kapur J, Elm J, Chamberlain JM, et al. Randomized trial of three anticonvulsant medications for status epilepticus. N Engl J Med. 2019; 381: 2103-2113.

[16] Janszky J, Holló A. Antiepileptics. In: Janszky J, Fogarasi A. (eds.) Clinical epileptology. [Antiepileptikumok. In: Janszky J, Fogarasi A. (szerk.) Klinikai epileptológia.] Medicina Könyvkiadó, Budapest, 2017; pp. 238-262. [Hungarian]

[17] Zhang Q, Yu Y, Lu Y et al. Systematic review and meta-analysis of propofol versus barbiturates for controlling refractory status epilepticus. BMC Neurol. 2019; 19: 55

[18] Shorvon S, Ferlisi M. The treatment of super-refractory status epilepticus: a critical review of available therapies and a clinical treatment protocol. Brain 2011; 134: 2802-2818.

[19] Kam PC, Cardone D. Propofol infusion syndrome. Anaesthesia 2007; 62: 690-701.

[20] Niermeijer JM, Uiterwaal CS, Van Donselaar CA. Propofol in status epilepticus: little evidence, many dangers? J Neurol. 2003 250: 1237-1240.

[21] Iizuka T, Kanazawa N, Kaneko J, et al. Cryptogenic NORSE: Its distinctive clinical features and response to immunotherapy. Neurol Neuroimmunol Neuroinflamm. 2017; 4: e396.
[22] Sculier C, Gaspard N. New onset refractory status epilepticus (NORSE). Seizure 2019; 68: 72-78.

[23] Böröcz K, Hayden Z, Mészáros V, et al. Autoimmune encephalitis: Possibilities in the laboratory investigation. [Az autoimmun encephalitisek laboratóriumi vizsgálati lehetőségei]. Orv Hetil. 2018; 159: 107-112. [Hungarian]

[24] Zima E. Target temperature in post-cardiac-arrest complex intensive care: Arguments for mild therapeutic hypothermia. [Célhőmérséklet a tartós újraélesztés utáni komplex intenzív kezelés során. Állásfoglalás az enyhe terápiás hypothermia mellett.] Orv Hetil. 2019; 160: 1840-1844. [Hungarian]

[25] Leitinger M, Trinka E, Gardella E, et al. Diagnostic accuracy of the Salzburg EEG criteria for non-convulsive status epilepticus: a retrospective study. Lancet Neurol. 2016; 15: 1054-1062.

(Janszky József dr., Pécs, Rét u. 2., 7623 e-mail: janszky.jozsef@pte.hu)

\section{"Ubi nihil timetur, quod timeatur nascitur." (Ha semmitől sem félnek, lesz, amitől féljenek.)}

A cikk a Creative Commons Attribution 4.0 International License (https://creativecommons.org/licenses/by/4.0/) feltételei szerint publikált Open Access közlemény melynek szellemében a cikk bármilyen médiumban szabadon felhasználható, megosztható és újraközölhető, feltéve, hogy az eredeti szerző és a közlés helye, illetve a CC License linkje és az esetlegesen végrehajtott módosítások feltüntetésre kerülnek. (SID_1) 